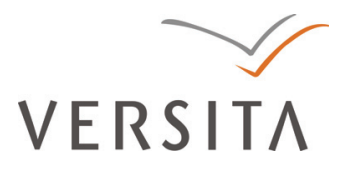

Folia Oeconomica Stetinensia

DOI: 10.2478/v10031-011-0018-x

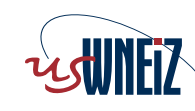

Wydzial Nauk Ekonomicznych i Zarządzania
Uniwersytetu Szczecińskiego

\title{
TERM STRUCTURE OF PUBLIC DEBT AND REFINANCING RISK \\ IN THE ECONOMIC AND MONETARY UNION
}

\author{
Tomasz Uryszek, Ph.D. \\ Institute of Finance, Banking and Insurance \\ Faculty of Economics and Sociology \\ University of Lodz \\ e-mail:tomasz.uryszek@uni.lodz.pl
}

Received 17 June 2011, Accepted 19 July 2011

\begin{abstract}
As public debt is an important factor influencing most countries' economies, the debt management seems to be crucial for the economy. Risk identification and minimizing is considered to be the most important aim of the debt management process, especially during economic slowdowns or crises. The main goal of the article is to assess the term structure and the level of refinancing risk in the in the Economic and Monetary Union (EMU) as a whole and in chosen EMU member states in particular. Refinancing risk is affected by the term structure of public debt. To monitor the level of this type of risk, not only the original maturity should be taken into account, but the residual maturity as well. Since the beginning of changes on the markets caused by the crisis, the volume of short-term public liabilities in the EMU countries has increased significantly, as well as the value of "debt to GDP" ratio. This could contribute to the overall increase in the level of refinancing risk. High share of short-term instruments in the structure of public debt in some EMU member states can cause problems with liquidity and solvency of their budgets. However, as an average, long-term instruments were mostly used to cover the financial needs of public sector in the EMU.
\end{abstract}

Keywords: public debt, management, refinancing risk, term structure, crisis.

JEL Classification: H63, H12. 


\section{Introduction}

The article discusses the issue of the refinancing risk in the process of public debt management. Monitoring and minimizing the level of this type of risk is especially important during an economic slowdown or crisis periods. High volumes of public borrowing in the euro area makes it necessary to monitor the level of the refinancing risk. Problems with the repayment of the public debt can lead to countries' insolvency. The main goal of the article is to assess the term structure and the level of refinancing risk in the in the Economic and Monetary Union (EMU) as a whole and in chosen EMU member states in particular. The empirical analyses of the whole EMU area as well as the chosen EMU member states were prepared. Those analyses are generally based on data derived from Eurostat and European Central Bank. The research period covers the years 1999-2010. Both quantitative and qualitative methods are used in the article.

\section{The problem of risk in the process of public debt management}

The public debt portfolio is usually the largest financial portfolio in a country. It frequently includes complex and risky financial structures, so it can expose the state's financial stability to a considerable risk. Huge and inappropriately constructed debt portfolios make governments vulnerable to economic and financial shocks and in many cases they are the main source of economic crises in the economy ${ }^{1}$.

Debt management must be approached actively to protect the budget against possible losses and provide the liquidity and solvency. Borrowing for the public authorities is a decision depending on the pursued policy, and the policy is largely based on country's economic situation as well as market players' judgments and opinions ${ }^{2}$. It is important to remember that the estimated levels of costs and risks should not be exceeded ${ }^{3}$. Risk minimization is perceived as an integral element of managing public debt ${ }^{4}$. Because of the variety of risks faced by a public borrower (refinancing risk, liquidity risk, settlement risk, interest rate risk, etc..$^{5}$ ) it is recommended that the risks should be assessed, monitored and minimized by countries' specialist government agencies ${ }^{6}$ or departments of ministries competent in the area of finance. In a growing number of cases, artificial intelligence methods (neural networks and genetic algorithms) are employed to reduce risk associated with issuing and redeeming Treasury debt ${ }^{7}$. Briefly speaking, the discussions of the ways of reducing risk that are presented in the literature ${ }^{8}$, recommend: minimising the debt service costs, expanding the market for Treasury securities, stretching the debt maturity periods 
or using diverse instruments to make debt management more flexible. All the tasks should be carried out concurrently, but attainment of the assumed goals is very difficult.

\section{Measuring the refinancing risk}

Refinancing risk (rollover risk) seems to be one of the most important factors influencing the process of the public debt management. It refers to problems that may appear once the floated debt has to be redeemed. The prerequisite for redeeming debt is availability of an adequate amount of funds and the most typical source of funds is new public borrowing. This leads to rolling over the public debt. This mechanism is common in most countries. Rollover risk appears when new debt has to be floated on terms that are very unfavourable to the state or - even worse - when it cannot be contracted at all. Debt incurred on unfavourable terms that actually come down to high debt servicing costs is comparable with interest rate risk being part of market risk. However, when debt cannot be rolled over or when it entails very high interest rates and an unfavourable maturity structure, then the state is exposed to financial crisis. The ramifications go far beyond the additional costs that the budget will have to pay. The huge scale of the phenomenon impacts not only the budget itself, but also the entire economy, including its real sphere, thus influencing the country's economic development. Therefore, the problem extends beyond purely financial effects on the budget and its consequences are much more penetrating ${ }^{9}$. For this reason, rollover risk is distinguished and treated separately from market risk involved in the State Treasury debt. Handling this type of risk is especially important for the developing countries ${ }^{10}$.

Refinancing risk is closely connected with the budget liquidity. The problem of liquidity appears when the government has already used up all available liquid assets and cannot meet, for any reason, its current borrowing needs. This situation is very dangerous for the whole economy, as the national budget and the entire budget sphere lose financial liquidity then, i.e. the capability of timely repayment of their obligations. This phenomenon is especially menacing in the longer term and so accurate predictions of maturity of the government obligations as well as ensuring the availability of adequate funds to repay the obligations become especially important.

Comprehensive actions that the World Bank and the International Monetary Fund recommend to reduce liquidity risk $^{11}$ are closely connected with the measures protecting against refinancing risk. Actions in support of state's short-term liquidity and minimising the short-term refinancing risk should include (among others) the efforts to extend the debt repayment periods. 
The maturity of public debt is very important from the perspective of managing the public debt portfolio. Debt maturity structure has an enormous impact on costs of public debt service. It also affects further issues of debt securities that are used to gain funds to repurchase the maturing liabilities. The term structure of public debt can be assessed by the criterion of the original or residual maturity. The first one informs about the length of the period for which the securities were initially issued. The second one defines the length of real time remaining to repurchase. In this way, medium or long-term bonds, which should be redeemed in the next 12 months or less, will be treated as short-term securities, regardless their original duration.

Refinancing risk is the lower, the longer the period to maturity is. Maturity measures applying to debt instruments have been known for a long time and they are broadly discussed in the literature of the subject ${ }^{12}$. The literature offers a whole range of theoretical models for measuring maturity of debt securities ${ }^{13}$. There are both simple and very sophisticated theoretical models for assessing refinancing risk. However, because of their construction or the way they approach variables not all of them have found practical application. A synthetic measure of refinancing risk is so-called average time to maturity (ATM). It is the average number of years after which the issued debt will have to be redeemed. Long periods to maturity expose to lower refinancing risk (because the need to raise funds to repay earlier debts is relatively less frequent). Hence, high ATM values stand for relatively low refinancing risk. The aforementioned ATM is an example of a refinancing risk measure that has been used in practice ${ }^{14}$.

\section{Public debt in the EMU Countries}

Official statistics of the EMU, provided by the Eurostat, were used for international comparisons. Due to different political systems of individual countries (unitary countries, federal states), the total values of public debt were taken into account (not just central government debt). Limiting the comparative analyses to the value of the Treasury debt could largely distort the real volume of the whole public debt of federal countries. The value of the public debt to GDP ratio in the EMU countries in the $3^{\text {rd }}$ quarter of 2010 is shown in Figure 1.

It is worth mentioning that the biggest problems with the values of public debt were noted in the "old" European Union countries (the "15-countries"), belonging to the euro area: Greece, Italy, Belgium, Ireland, Portugal, France, Germany, and Austria. These countries did not meet the fiscal criterion of the Maastricht Treaty, concerning the volume of public debt. The debt should not exceed $60 \%$ of GDP. Among the "new" EU and euro-zone member states (admitted to the Union in 2004 or later) Malta, and Cyprus have had problems with the amount of public 


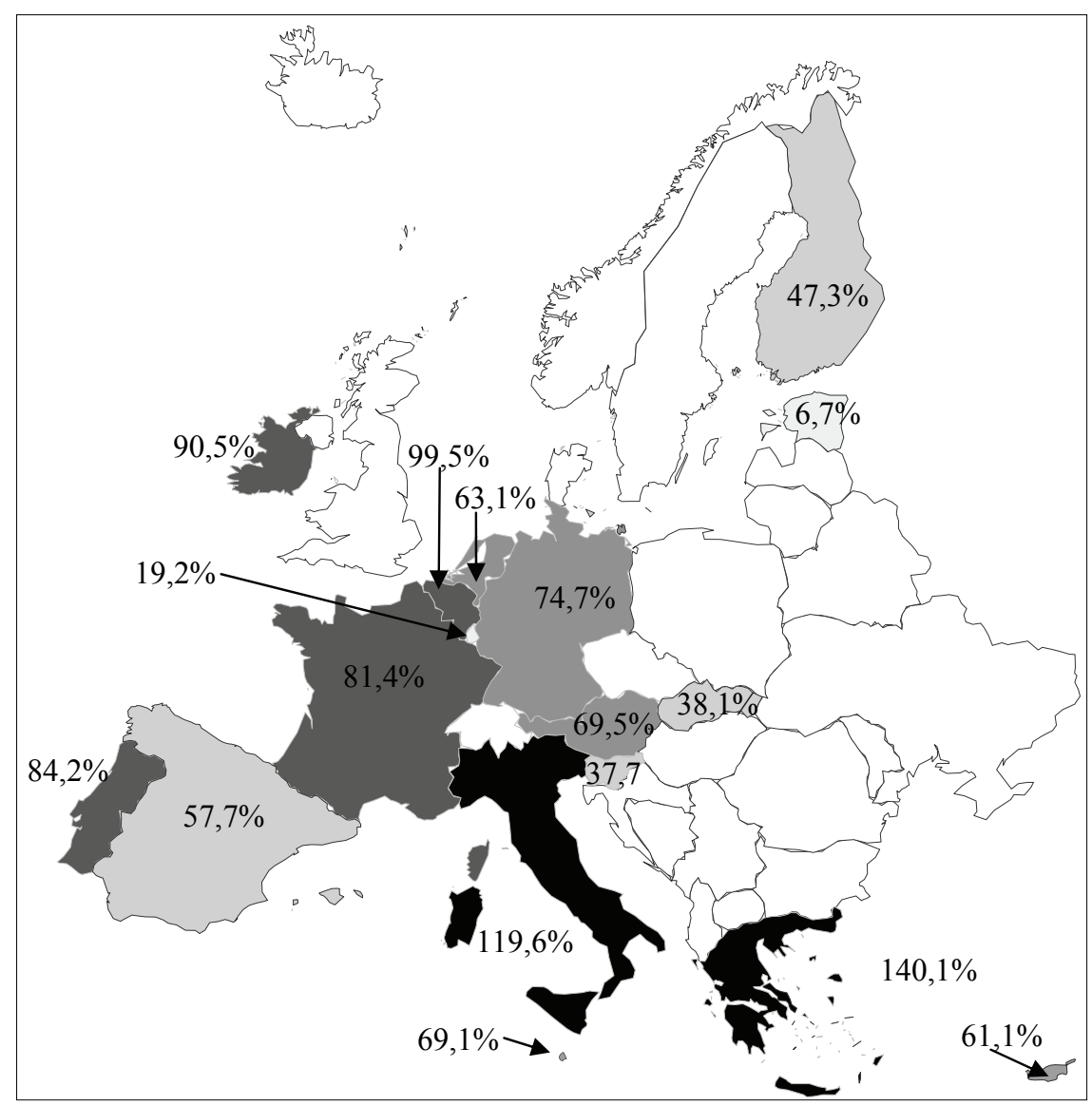

Fig. 1. Value of public debt to GDP ratio in the EMU ${ }^{15}$ countries in the $3^{\text {rd }}$ quarter of 2010 Source: own elaboration based on Eurostat data.

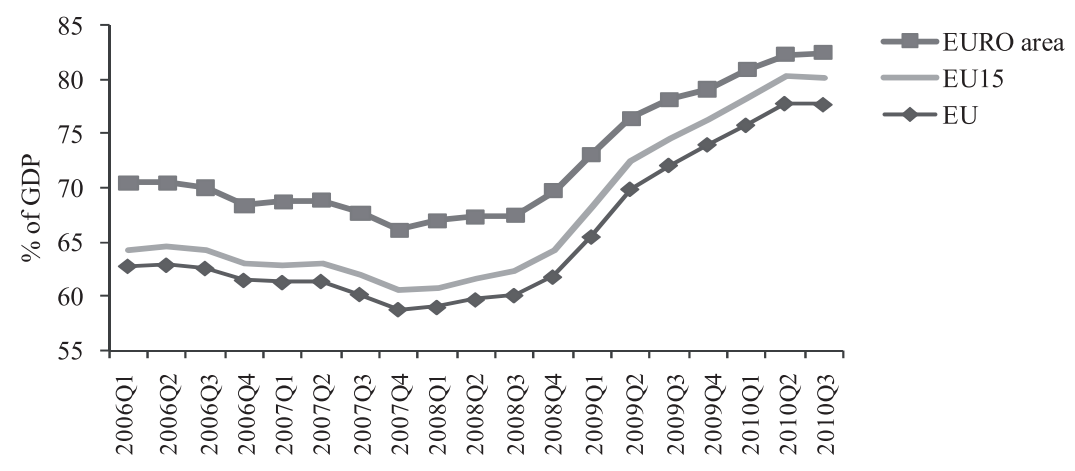

Fig. 2. Public debt in EMU and EU countries

Source: own elaboration based on Eurostat data. 
debt. It should be noted that the situation with regard to public debt of EMU member states has deteriorated significantly in recent years, which is related to the global economic slowdown (crisis). This does not mean that all EMU countries fulfilled the debt limit in the past. Details are presented in Figure 2.

Analysis of the data contained in Figure 2 clearly indicates that the period of economic development has allowed the EMU countries (a well as the EU member states) to reduce the average value of public debt to GDP ratio. After the "explosion" of the crisis, this trend was reversed. That was the result of rising budget deficits in European countries, due to an increase in budgetary expenditure (anti-crisis programs, increased social spending, etc.).

\section{Average time to maturity of public debt in the EMU}

The value of ATM index shows the average number of years after which the debt will have to be redeemed. Longer time to maturity means lower level of refinancing risk. The average time to maturity in the whole EMU is shown in Figure 3.

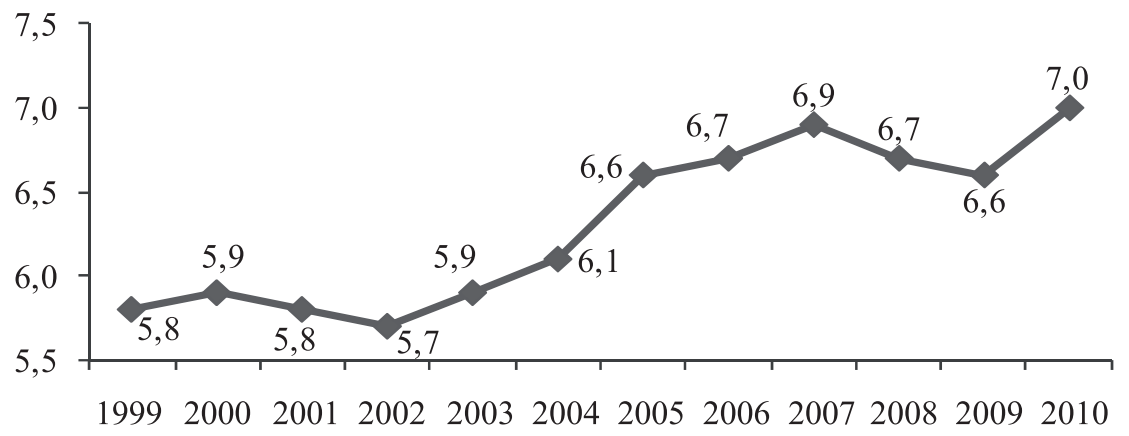

Fig. 3. Average time to maturity of public debt instruments in the EMU

Source: own elaboration based on European Central Bank data.

Figure 3 presents a growing ATM value calculated for the public debt in the EMU. Accordingly, the refinancing risk of the debt exhibits a downward trend. On the other hand, the average terms to maturity are short enough to declare that there is no real threat of transferring the debt on future generations. That should be assessed positively. ATM is a synthetic indicator, which is affected by the maturity structure of public debt the particular countries within the euro zone. This structure will be analyzed in detail further in this article. 


\section{Original VS. residual maturity of the PUBLIC debt in the EMU}

The necessity to finance budget deficits in the EMU member states resulted in the increase of public debts. In addition, the "new" debt was largely short-term. That affected the negative assessment of the level of refinancing risk in public debt management. The scale of the usage short-term debt instruments (with maturities up to 1 year) in EMU countries is presented in Figure 4.

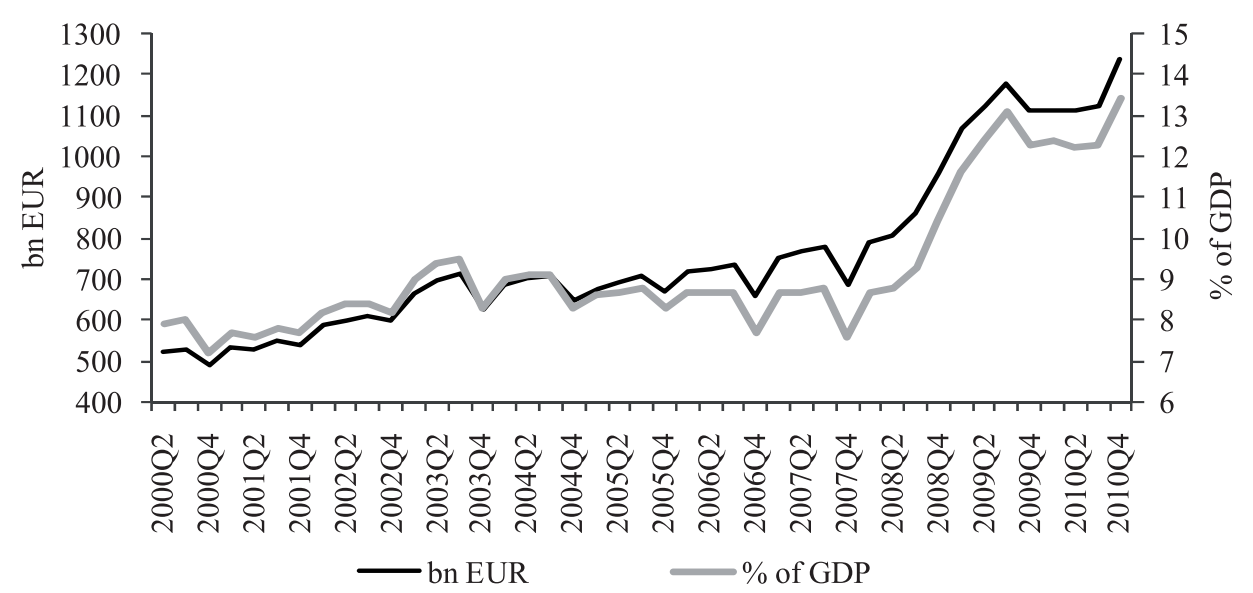

Fig. 4. The volume of the issues of short-term Treasury securities in the EU Source: own elaboration based on Eurostat data.

Prior to the financial crisis, short-term instruments were used on a relatively small scale. Small increase of the volume of short-term debt (in the "pre-crisis" period) was partly covered by the increase in GDP. That is why the value of "short-term debt to GDP" ratio had been fluctuating but not raising. Since the beginning of changes on the markets caused by the crisis, the volume of short-term liabilities increased significantly, as well as the value of "short-term debt to GDP" ratio. It means that public authorities of the EMU countries (as an average) have begun to use these instruments on a much larger scale to maintain the liquidity of their budgets. This could contribute to the overall increase in the level of refinancing risk and - indirectly deteriorations of interest rate risk of public debt in the EMU countries. However, the short-term instruments have been used in the EMU much less frequently than the long-term instruments. It is shown in Figure 5.

The share of short-term instruments in the total volume of public debt (by original maturity) was low. In the years 1999-2007 it was around 10-12\%. The financial crisis resulted 
in an increase of share of these instruments in the debt structure of the General Government to near $14-16 \%$. We can conclude that the financial crisis has affected in the increased use of short-term debt instruments. However it was not a very significant impact, because the longterm instruments were mostly used to cover the financial needs of public sector in the EMU.

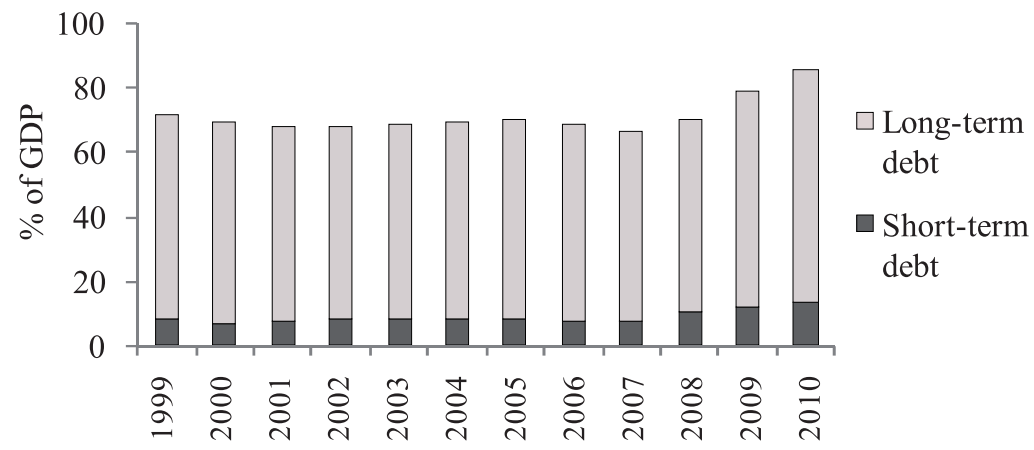

Fig. 5. Term structure of General Government debt in the EMU (original maturity) Source: own elaboration based on Eurostat data.

The original maturity of the debt should be compared with the residual maturity. It can be helpful in the assessment of the level of refinancing risk. The term structure (by the residual maturity) of public debt in the EMU is shown in Figure 6.

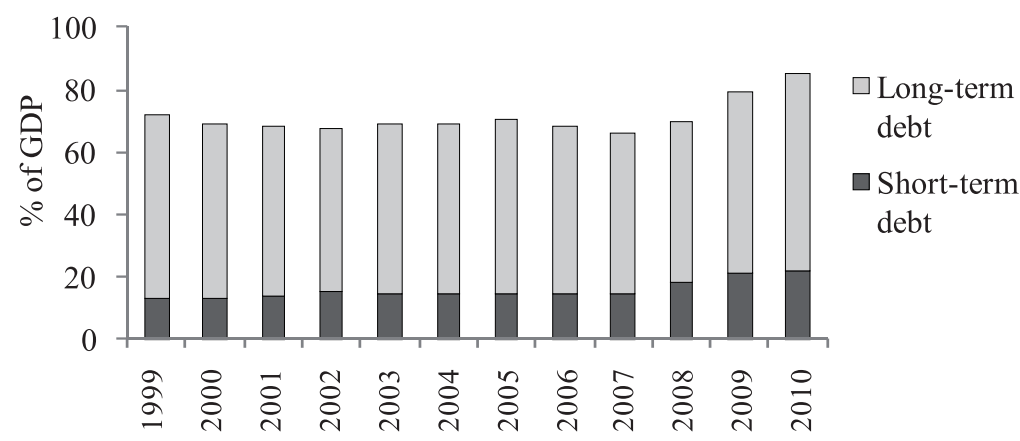

Fig. 6. Term structure of General Government debt in the EMU (residual maturity) Source: own elaboration based on European Central Bank data.

The share of short-term instruments (according to the residual maturity) showed in Figure 6 is slightly higher than the one illustrated in Figure 5 (according to the original maturity). This is 
due to the fact that long-term instruments, which are to be redeemed in less than a year are treated to be short-term in this case. The term structure of public debt, according the residual maturity, indicate that more than $25 \%$ of the public debt occurred short-term in 2010 (and the volume of that debt was more than $20 \%$ of GDP in EMU). It means, that a significant part of the debt must be paid back in a less than one year. As financial means for those payments are gained from the "new" public borrowing, that situation negatively affect the level of the refinancing risk.

The similar situation appeared in the EMU member states. However the differences between particular countries were significant. The share of short-term instruments in the total volume of public debt (according to original vs. residual time to maturity) of three chosen EMU member states in the light of the average for the whole EMU was shown in Table 1.

Table 1. The share of short-term debt instruments in the volume of public debt in chosen EMU countries (original vs. residual maturity) (\%)

\begin{tabular}{|c|c|c|c|c|c|c|c|c|}
\hline \multirow{2}{*}{ Year } & \multicolumn{2}{|c|}{ EMU } & \multicolumn{2}{c|}{ Greece } & \multicolumn{2}{c|}{ Estonia } & \multicolumn{2}{c|}{ Portugal } \\
\cline { 2 - 9 } & original & residual & original & residual & original & residual & original & residual \\
\hline 1999 & 11.30 & 18.83 & 3.94 & 8.51 & 3.08 & 20.09 & 16.36 & 33.54 \\
\hline 2000 & 10.42 & 19.31 & 3.29 & 8.50 & 1.96 & 17.57 & 17.08 & 30.44 \\
\hline 2001 & 11.31 & 20.12 & 1.54 & 12.34 & 4.17 & 10.32 & 19.49 & 34.07 \\
\hline 2002 & 12.06 & 22.82 & 1.38 & 20.96 & 3.51 & 2.27 & 15.24 & 33.56 \\
\hline 2003 & 12.03 & 21.51 & 2.46 & 17.92 & 3.57 & 1.68 & 19.86 & 42.18 \\
\hline 2004 & 11.94 & 21.31 & 2.03 & 17.76 & 0.00 & 1.62 & 26.09 & 55.71 \\
\hline 2005 & 11.84 & 21.15 & 1.40 & 12.98 & 2.17 & 7.46 & 25.64 & 47.99 \\
\hline 2006 & 11.26 & 21.02 & 1.51 & 14.37 & 0.00 & 18.89 & 23.63 & 45.76 \\
\hline 2007 & 11.46 & 22.64 & 1.14 & 11.74 & 2.63 & 10.48 & 23.46 & 50.58 \\
\hline 2008 & 14.88 & 26.66 & 2.44 & 14.06 & 2.13 & 18.88 & 25.66 & 46.01 \\
\hline 2009 & 15.53 & 26.39 & 4.57 & 10.56 & 1.39 & 11.76 & 24.61 & 41.92 \\
\hline 2010 & 15.71 & 26.07 & 3.92 & 11.40 & 0.00 & 9.09 & 22.26 & 41.94 \\
\hline
\end{tabular}

Source: own elaboration based on European Central Bank data.

Table 1 contains the data for the whole EMU (an average, estimated by European Central Bank), Greece, Estonia and Portugal. All these three countries are in a completely different economic situation (see Figure 1). It is very interesting that the share of short-term instruments in the structure of public debt in the most heavily indebted country as well in least indebted state among the euro zone was similarly low. This can be interpreted as the result of deliberate policy of public debt management, which allowed the use of short-term debt instruments to a small extent. That actions enabled a reduction of the level of refinancing risk. The situation of 
Portugal is completely different. This country, due to a significant share of short-term securities in the total volume of its public debt, faced a problem of a high level of the refinancing risk.

\section{The volume of short-term public debt in the EMU}

The reduction of short-term liabilities is particularly important in countries characterized by very high values of public debt (e.g. in Greece or Italy). Diminishing the scale of the issue of short-term debt instruments should be assessed positively as it allows the extension of debt repayments over a longer period. The volumes of the short-term public debt instruments (according to the residual maturity) in the EMU member states (as a percentage of their GDP's) are illustrated in Table 2.

Table 2. The volumes of short-term public debt in the EMU member states (according to the residual in \% of GDP)

\begin{tabular}{|l|r|r|r|r|r|r|r|r|r|r|r|r|}
\hline Country & 1999 & 2000 & 2001 & 2002 & 2003 & 2004 & 2005 & 2006 & 2007 & 2008 & 2009 & 2010 \\
\hline Austria & 6.0 & 6.2 & 7.3 & 8.3 & 8.2 & 8.1 & 7.3 & 8.1 & 3.4 & 8.2 & 6.1 & n.a. \\
\hline Belgium & 24.1 & 21.4 & 17.9 & 17.3 & 16.8 & 16.7 & 16.1 & 16.5 & 18.5 & 22.0 & 22.9 & 23.2 \\
\hline Cyprus & 19.6 & 22.1 & 30.0 & 14.3 & 16.7 & 14.0 & 14.7 & 10.9 & 14.2 & 12.1 & 10.8 & 6.4 \\
\hline Germ. & 8.4 & 8.0 & 9.4 & 10.2 & 11.4 & 12.0 & 12.4 & 13.1 & 13.1 & 13.9 & 16.1 & 23.3 \\
\hline Estonia & 0.8 & 0.5 & 0.4 & 0.1 & 0.1 & 0.1 & 0.4 & 1.0 & 0.5 & 0.7 & 0.6 & 0.5 \\
\hline Spain & 13.2 & 11.6 & 10.4 & 11.0 & 9.8 & 8.8 & 7.7 & 7.1 & 6.7 & 8.7 & 12.6 & 12.9 \\
\hline Finland & 6.9 & 8.9 & 8.6 & 10.7 & 10.8 & 7.5 & 8.4 & 9.2 & 7.9 & 7.9 & 11.0 & 11.6 \\
\hline France & n.a. & n.a. & n.a. & n.a. & n.a. & n.a. & n.a. & n.a. & 16.9 & 22.4 & 28.8 & 27.4 \\
\hline Greece & 7.9 & 8.1 & 11.4 & 17.6 & 14.8 & 14.9 & 12.5 & 13.4 & 11.1 & 13.7 & 12.2 & 14.6 \\
\hline Ireland & n.a. & n.a. & n.a. & n.a. & n.a. & n.a. & n.a. & n.a. & n.a. & n.a. & n.a. & n.a. \\
\hline Italy & 30.3 & 32.2 & 32.9 & 35.4 & 28.2 & 28.4 & 29.2 & 29.4 & 27.7 & 30.9 & 32.6 & 29.9 \\
\hline Luxem. & 0.4 & 0.4 & 0.7 & 1.5 & 1.4 & 1.9 & 2.0 & 1.6 & 1.3 & 1.4 & 1.6 & 1.7 \\
\hline Malta & 11.7 & 12.8 & 14.4 & 14.5 & 16.4 & 16.4 & 12.2 & 11.1 & 9.2 & 11.4 & 12.6 & 9.3 \\
\hline Netherl. & 8.9 & 8.4 & 10.1 & 11.6 & 10.7 & 10.8 & 10.9 & 9.7 & 9.6 & 23.7 & 18.0 & n.a. \\
\hline Portugal & 12.4 & 11.3 & 13.0 & 13.5 & 16.6 & 20.6 & 20.3 & 21.8 & 22.9 & 22.6 & 24.5 & 27.5 \\
\hline Slovenia & 2.3 & 3.7 & 2.5 & 3.2 & 3.2 & 4.3 & 3.5 & 2.9 & 3.0 & 2.7 & 5.7 & 3.4 \\
\hline Slovakia & n.a. & n.a. & n.a. & n.a. & n.a. & n.a. & 3.4 & 3.7 & 2.8 & 5.5 & 5.9 & 5.6 \\
\hline n.a. - data & & & & & & & & & & \\
\hline
\end{tabular}

n.a. - data not available.

Source: own elaboration based on European Central Bank data.

Excessively high volumes of short-term public debt instruments in some countries listed in Table 2 can cause problems with liquidity and solvency of their budgets. Paradoxically, 
a country characterized by a lower value of debt in relation to its GDP may have greater problems with maintaining an adequate level of liquidity and significantly higher level of refinancing risk than a country with a much higher ratio of debt to GDP. Some countries (i.e. Portugal, Italy, France, Belgium and Germany) have to pay more attention to the term structure of public debt. These countries have to repay short-term liabilities (maturing within one year or less) in amounts equal to 20 percent (or even more) of their annual GDP. Furthermore, the rapid growth of these liabilities in the last few years - in Portugal, France and Germany - may cause solvency problems of these countries, especially, that all of them do not meet the Maastricht fiscal criterion for public sector debt.

\section{Conclusions}

The results of the research show that the term structure of public debt in the EMU has changed during the last few years. It was partly affected by the crisis: government demand for funds has been largely met through the short-term public borrowing. Since the beginning of changes on the markets caused by the crisis, the volume of short-term public liabilities in the EMU countries increased significantly, as well as the value of "debt to GDP" ratio. This could contribute to the overall increase in the level of refinancing risk. On the other hand, the average time to maturity of public debt in the EMU has increased during the last year, which is a positive tendency.

The changes in the refinancing risk level have differed between examined countries. Some highly indebted countries, regardless to their serious economic problems, have used the shortterm borrowing to a small extent, and in this way they tried to diminish the refinancing risk (e.g. Greece). Other indebted countries, however, (e.g. Portugal) have to pay more attention for the term structure of their debt. High share of short-term instruments in the structure of public debt in those EMU member states increases the level of the refinancing risk and can cause problems with liquidity and solvency of their budgets.

\section{Notes}

1 IMF (2001), p. 2, v.

2 Asach (1999).

3 IMF (2001), p. 1.

4 OECD (2005), pp. 115-117.

5 See Piotrowska-Marczak, Uryszek (2009), pp. 90-92

6 Janecki (2001). 
7 More in Klukowski and Kuba (2004), pp. 4-12.

8 The report of the Financial Stability Forum criticizes national debt management concentrated on minimizing the costs of its service and risks. The preferred approach emphasizes debt portfolio management that protects against crises and financial destabilization; see more in Financial Stability Forum (2000), p. 14.

9 IMF (2001), p. 11.

${ }^{10}$ Ibidem, p. 11.

${ }^{11}$ See IMF (2002), p. 298.

12 See for instance Luckett (1964), pp. 148-157.

13 See for instance Nawalkha and Lacey (1988), pp. 82-84.

14 The Polish Ministry of Finance uses the ATM for estimating refinancing risk involved in the Treasury securities.

${ }^{15}$ Estonia Joined EMU In 2011, however it has been included into the analyses.

\section{References}

Asach, R.L. (1999). Politics and Public Debt. The Dominion, the Banks and Alberta's Social Credit. Edmonton: University of Alberta Press.

Financial Stability Forum (2000). Report of the Working Group on Capital Flows. $10^{\text {th }}$ June 2011. http://www.financialstabilityboard.org/publications/r_0004.pdf.

IMF (2001). Guidelines for Public Debt Management. Prepared by the Staffs of the International Monetary Fund and the World Bank. IMF and World Bank.

IMF (2002). Guidelines for Public Debt Management: Accompanying Document. Prepared by the Staffs of the International Monetary Fund and the World Bank. IMF and World Bank.

Janecki, J. (2001). Agencja lekiem na dług, Rzeczpospolita, 115.

Klukowski, L. Kuba, E. (2004). Koncepcja zastosowania metod sztucznej inteligencji w zarządzaniu długiem Skarbu Państwa, Bank i Kredyt, 2, pp. 4-13.

Luckett, D.G. (1964). On Maturity Measures of the Public Debt. Quarterly Journal of Economics, Vol. 78, Issue 1, pp. 148-157.

Ministry of Finance of the Republic of Poland (2011), homepage of the MFRP. $10^{\text {th }}$ June 2011, http://www.mf.gov.pl/_files_/dlug_publiczny/zadluzenie/szeregi/zadluzenie_skarbu_ panstwa.exe.

Nawalkha, S.K., Lacey, N.J. (1988). Closed-form Solutions of Higher-Order Duration Measures, Financial Analysts Journal, Vol. 44, Issue 6, pp. 82-84.

OECD (2005). Overview of Advances in Risk Management of Government Debt. Financial Market Trends, Issue 88, pp. 115-134.

Piotrowska-Marczak K., Uryszek T. (2009). Zarzadzanie finansami publicznymi. Warszawa: Difin. 